\title{
Physicochemical properties of banana peel powder in functional food products
}

\author{
*Mohd Dom, Z., Mujianto, L. Azhar, A., Masaudin, S. and Samsudin, R. \\ Department of Process and Food Engineering, Universiti Putra Malaysia, 43400 UPM Serdang, Selangor \\ Darul Ehsan, Malaysia
}

\author{
Article history: \\ Received: 4 May 2020 \\ Received in revised form: 5 \\ May 2021 \\ Accepted: 19 May 2021 \\ Available Online: 23 May \\ 2021
}

\section{Keywords:}

Saba banana,

Banana peel,

Banana peel powder,

Water holding capacity,

Oil holding capacity

DOI:

https://doi.org/10.26656/fr.2017.5(S1).037

\begin{abstract}
Saba banana is one of the most favourite banana varieties in Malaysia. It also generates a concerning amount of waste as the only value part is the pulp. Banana peel has been proven to have a lot of nutritional content that should not be ignored and wasted. Conversion of banana peel to powder will convert it into a value-added product in the food industry. Preliminary study on the protein, moisture, crude fibre and fat was carried out for 2 different stages of maturity which are stage 2 (light green) and stage 5 (yellow with green tips). Both stages have almost similar proximate analysis values and hence stage 2 of banana was chosen for the next analysis, due to the high waste of banana peel in stage 2 in SME (Small Medium Enterprise) in the production of banana chips. This study characterized the banana peel powder for storage application at different sizes of particles which are $1-125 \mu \mathrm{m}, 126-250 \mu \mathrm{m}$ and $>250 \mu \mathrm{m}$. As the particles of the banana peel powder increases, the flowability of the powder decreases. It was found that green banana peel (stage 2) at sample A $(1-125 \mu \mathrm{m})$ has the highest true density, but sample $\mathrm{C}(>250$ $\mu \mathrm{m})$ has the highest bulk density. The $\mathrm{pH}$ mean value of the three sizes also ranges from 6.15 to 6.46 . The powder's $\mathrm{pH}(6.15-6.46)$ is in the standard wheat flour acidity range. Moreover, the study on the water holding capacity at different temperatures identifies that banana peel powder has a high water holding capacity ranging from 3.83 to $6.45 \mathrm{~g}$ water $/ \mathrm{g}$ dry sample. In short, this study is a success in identifying the potential of banana peel powder in food products based on its characteristics.
\end{abstract}

\section{Introduction}

Saba banana is a triploid ABB that is produced in liquid form cells derived from multiplying and known in several southeast Asia countries as Pisang Kepok in Indonesia, Pisang Nipah (Malaysia), and Kluai Hin in Thailand (Valmayor et al., 2000). It belongs to the dominant group of Balbasiana and some characteristics of Acuminata varieties. The colour of its peel is green when unripe and turns yellow when ripe. It has thick peels. Each bunch can weigh a maximum of $28 \mathrm{~kg}$ and has about 12-18 hands in each bunch (Dela Cruz et al., 2008). In the Philippines, Saba banana varieties hold $18 \%$ of total banana production (Authority, 2017). Saba banana also has its commercial attraction among other local and commercial banana varieties present in Malaysia. It is very popular as a cooking banana either in ripe or unripe state and rarely eaten fresh. The ripening stages of the banana were determined by using a scale from 1 to 7 from ripe to an unripe banana. There are differences in the colours of bananas as more mature bananas are more yellowish rather than immature bananas. Bananas on the unripe stages 2 are utilised as raw material for the banana chips production industry aside from Pisang Tanduk and Pisang Nangka. Meanwhile, bananas on the ripe stages 5 are fried as banana fritters by street vendors in Malaysia and very popular for household buyers for Malaysian cuisines.

During most food productions, only the flesh of the Saba banana has been processed while the peels will go to waste. The banana peel represents $40 \%$ of the total weight of fresh bananas and as a result, 200 tonnes of waste from banana peels were generated each day in Malaysia and its trend is increasing (FAMA, 2007). Among Malaysian adults, banana comes as the second most consumed fruit weekly compared to other fruits available (Othman et al., 2013). According to Reference info not provided.

A single banana helps fulfil $23 \%$ of daily potassium needs. It also contains many essential vitamins like A, 
B6, C and D. Besides, some banana varieties also are rich sources of secondary antioxidants (Shian et al., 2012).

In spite of all the beneficial nutrients of banana pulp consumption, the cultivation of bananas also raises issues on waste disposal like peel, leaf and pseudostem for farmers and food processing mills. Only $60 \%$ of the total weight of bananas is utilised and the remaining are often ignored as waste (Tchobanoglous et al., 1993). Other reports also highlight the amount of potential waste from banana peels alone is 35\% (Gupta and Joshi, 2000; Gowe Chala, 2015). The yield of banana peel has not deviated too much as found by Anhwange et al., (2009) which is about $33.81 \pm 0.56 \%$ per $100 \mathrm{~g}$ fresh weight.

In this study, the research is done to determine the chemical and physical properties of banana peel. A strategic plan has been developed by the Department of Agriculture Malaysia to increase the production of bananas from 2250 tons in 2016 to 27,000 tan in 2020 (Department of Agriculture, 2016). Despite the massive cultivation of bananas in future, the waste generated from the agricultural and food processing industry can be accumulated since other parts of the banana are considered as waste except for the pulp. Despite being the focus of interest by various studies on the utilisation of banana peels in food production, the studies on the physical properties of banana peel powder suitable for storage are limited.

The commercialization of the banana peel powder surely needs a method of preservation in which in this case study is through drying. Drying causes the partial water content removed by evaporation until it reaches a safe level of moisture content for storage. The idea to form Saba banana peel in a powder form is to overcome the potential accumulation of banana peel waste that is due to the massive attention from the government to expand the land of Saba banana cultivation in future. Banana peel does have the potential to be developed into food products such as gelling, thickening and stabilising agents (Jun et al., 2006). This project was aimed to study the physicochemical properties of banana peel powder such as the moisture content, water holding capacity, oil holding capacity and their related properties. This project also aims to evaluate the potential use of banana peels to improve storage.

\section{Materials and methods}

\subsection{Material}

Saba banana was bought from Pasar Borong Selangor at stage 2 and stage 5 of maturation. A cluster of bananas was randomly picked from a banana bunch.
The fruits were selected based on their uniformity of colour and less bruise.

\subsection{Banana peel powder preparation}

A cluster of bananas was then separated from the bunch and the stalks were removed. Then, the banana was rinsed several times with tap water and last rinsed with distilled water. After that, the banana was then peeled and immersed in $0.5 \%$ citric acid solution. The peels were then cut and immersed into the citric acid solution and drained. Then the peels were dried in the oven (Memmert Oven) at $60^{\circ} \mathrm{C}$ until no more sap can be seen when breaking apart the sample in $72 \mathrm{hrs}$ and $84 \mathrm{hrs}$ for stage 2 and stage 5 of banana peel respectively. Then, the banana peels were milled for about 30 mins with intervals. The milled powder was then sieved with size distribution according to Table 1 .

Table 1. Particle size range of 3 different sieving mesh value

\begin{tabular}{cc}
\hline Sample & Size of particles range, $\mu \mathrm{m}$ \\
\hline A & $\leq 125$ \\
B & $126-250$ \\
C & $\geq 251$ \\
\hline
\end{tabular}

\subsection{Proximate analysis}

\subsubsection{Moisture content}

A $5 \mathrm{~g}$ sample was analysed and its moisture content is measured by using a moisture analyser (MX-50, A and $\mathrm{D}$ Weighing, San Jose, America) at $105^{\circ} \mathrm{C}$ until it reaches constant weight. The moisture content is in wet basis by this formula:

$$
M C=\frac{m_{i}-m_{f}}{m_{i}} \times 100
$$

\subsubsection{Crude fiber, protein, and fat}

Crude protein is analyzed by the Kjeldahl method (AOAC, 2000) with factor 6.32. The protein and fat analysis also used methods from AOAC (2000).

\subsection{Physical properties}

\subsubsection{Tapped density $\left(\rho_{\text {tap }}\right)$}

Tapped density $\left(\rho_{\text {tap }}\right)$ was determined in a $25.4 \mathrm{~mm}$ chamber internal diameter in a (GeoPyc 1360 Density Analyzer, Micrometrics', USA) with $2 \mathrm{~g}$ of sample. The test is carried out for 5 cycles with a typical force of 51 $\mathrm{N}$.

\subsubsection{Bulk density $\left(\rho_{\text {bulk }}\right)$}

Bulk density was determined by filling a $15 \mathrm{~mL}$ measuring cylinder with banana peel powder. The mass of banana peel needed to fill in the measuring cylinder is recorded and the bulk density is calculated as follows:

$$
\text { Bulk density }\left(\frac{\mathrm{g}}{\mathrm{cm}^{3}}\right)=\frac{\text { Mass of powder, } g}{\text { Volume of powder, } \mathrm{Cm}^{3}}
$$




\subsubsection{True density $\left(\rho_{\text {true }}\right)$}

The true density was determined in the gas pycnometer (AccuPyc II 1340 TEC, Micrometrics', USA) with 5 cycles in $1.0 \mathrm{~cm}^{3}$ chamber volume.

\subsection{Flowability}

\subsubsection{Carr Index (CI)}

The powder's flowability and cohesiveness of the powder were determined in terms of Carr Index (Carr, 1965; Turchiulli et al., 2005) by the following formula:

$$
C I=\frac{\rho_{\text {tap }}-\rho_{\text {bulk }}}{\rho_{\text {tap }}} \times 100
$$

\subsubsection{Hausner ratio (HR)}

Hausner ratio was calculated to determine the flowability and cohesiveness of the banana peel powder through the following formula:-

$$
H R=\frac{\rho_{\text {tap }}}{\rho_{\text {bulk }}}
$$

\section{$2.6 \mathrm{pH}$}

From the $2 \mathrm{~g}$ of banana peel powder, $4 \%$ of the mass was weighed by using a weighing balance. Then, the powder was poured into the centrifuge tube and added with $15 \mathrm{~mL}$ of distilled water. Then it is poured into 15 $\mathrm{mL}$ distilled water. After that, the mixture was vortexed for 5 mins and let stand for another 30 mins. The acidity of the supernatant was measured by using $(\mathrm{pH}$ meter, Sartorius, Germany).

\subsection{Water holding capacity (WHC)}

The WHC determination was referred to and modified from methods applied by (Wachirasiri et al., 2009). The $2 \mathrm{~g}$ of banana peel powder sample was weighed on an electronic balance. Then the sample was put into the centrifugal tube with $25 \mathrm{~m}$ distilled water. Then, the lid was closed and vortexed for about 5 mins until the water and banana peel powder mixed well. Then the centrifuge tube was heated in a $40^{\circ} \mathrm{C}$ water bath. After that, the mixture was centrifuged for 25 mins at $3000 \mathrm{rpm}$ at room temperature $\left(25^{\circ} \mathrm{C}\right)$. The supernatant was decanted carefully, and the mass left in the tube was measured by using an electronic balance. Another test with a similar method was carried out by replacing the heating temperature from $40^{\circ} \mathrm{C}$ into $60^{\circ} \mathrm{C}$ and $80^{\circ} \mathrm{C}$ in order to optimize the suitable thermal treatment.

\subsection{Oil holding capacity $(\mathrm{OHC})$}

The $2 \mathrm{~g}$ of banana peel powder sample was weighed on an electronic balance. Then the sample was put into the centrifugal tube and with $25 \mathrm{~m}$ cooking palm oil (Seri Murni, Malaysia). Then, the lid was closed and vortexed for about 5 mins until the water and banana peel powder was homogenised. Then the centrifuge tube was heated in a $40^{\circ} \mathrm{C}$ water bath. After that, the mixture was centrifuged for $25 \mathrm{mins}$ at $3000 \mathrm{rpm}$. The supernatant was decanted carefully and the mass left in the tube was measured by using an electronic balance. Another test with a similar method was carried out by replacing the heating temperature from $40^{\circ} \mathrm{C}$ to $60^{\circ} \mathrm{C}$ and $80^{\circ} \mathrm{C}$. All analysis was done in triplicate.

\section{Results and discussion}

\subsection{Proximate analysis of stage 2 and 5 of banana peels powder}

The proximate analysis is to identify the components percentage content after the drying. The applied heat can cause denaturation of some protein molecules that affect its agglomeration and its cohesiveness properties. Moisture content in food samples may affect the product stability, powder flow properties and microbial growth (Tomar et al., 2017).

From Table 2 the amount of crude fibres for 2 and 5 stages shows the least value compared to the other components which are $4.8 \% \mathrm{w} / \mathrm{w}$ and $5.4 \% \mathrm{w} / \mathrm{w}$ respectively. However, protein fat and crude fibre of banana peels have a higher value compared to the finding by A et al. (2016) using the banana peels. As the moisture is reduced the amount of fat can be identified compared to the fresh proximate analysis by A et al. (2016). Contradictory, the amount of crude fibre is much lower than found by A et al. (2016) at $2.15 \%$ at the fresh state of stage 2 mature green Saba banana. From the results obtained both stages have a close difference value and hence stage 2 of banana was chosen for the next analysis, it is due to the high waste of banana peel in stage 2 in SME (Small Medium Enterprise) in the production of banana chips.

Table 2. Preliminary study of proximate analysis for stage 2 and stage 5 of saba banana peel

\begin{tabular}{ccc}
\hline Proximate component & $\begin{array}{c}\text { Stage 2 of saba } \\
\text { banana peel }\end{array}$ & $\begin{array}{c}\text { Stage 5 of saba } \\
\text { banana peel }\end{array}$ \\
\hline Moisture $(\% \mathrm{w} / \mathrm{w})$ & 9.18 & 9.2 \\
Crude protein $(\% \mathrm{w} / \mathrm{w})$ & 4.8 & 5.4 \\
Fat $(\% \mathrm{w} / \mathrm{w})$ & 4.8 & 3.8 \\
Crude fibre $(\% \mathrm{w} / \mathrm{w})$ & 1.3 & 1.8 \\
\hline
\end{tabular}

\subsection{Density}

The next study is to focus more on the particle size variation of stage 2 banana peel powder. Stage 2 banana peel is more suitable for the industry as it is more practical to control the quality of output and have slow oxidation compared to stage 5 ripe bananas. Stage 5 ripe banana peels are perishable and hard to set the operating condition due to the varied distance of peel sources. 
Table 3 shows the true density of the banana peels flour which sample A for size ranges of particle of 125 $\mu \mathrm{m}$ and less, Sample B size between 126-250 $\mu \mathrm{m}$ and Sample $C$ is $251 \mu \mathrm{m}$ and above. The result was decreasing from $1.4991 \mathrm{~g} / \mathrm{cm}^{3}$ to $1.3815 \mathrm{~g} / \mathrm{cm}^{3}$ as the range size of the particle was increased. This is because the volume is increasing as the number of voids also increases. Besides, the bulk density of the powder increases as the particle size range increases with sample $\mathrm{C}(>250 \mu \mathrm{m})$ showing the highest value at $0.5660 \pm 0.14$. The increase of bulk density could be attributed to the less volume of the void between particles (Berk 2013).

Table 3. The tap, true and bulk density of Saba banana peel powder for sample A $(\leq 125 \mu \mathrm{m})$, B $(126-250 \mu \mathrm{m})$ and C $(\geq 251$ $\mu \mathrm{m})$

\begin{tabular}{cccc}
\hline Sample & $\begin{array}{c}\text { Tap Density } \\
(\mathrm{g} / \mathrm{mL})\end{array}$ & $\begin{array}{c}\text { True Density } \\
(\mathrm{g} / \mathrm{mL})\end{array}$ & $\begin{array}{c}\text { Bulk Density } \\
(\mathrm{g} / \mathrm{mL})\end{array}$ \\
\hline $\mathrm{A}$ & $0.6628 \pm 0.0051$ & $1.4991 \pm 0.0014$ & $0.3878 \pm 0.12$ \\
$\mathrm{~B}$ & $0.6996 \pm 0.0061$ & $1.4365 \pm 0.0071$ & $0.4714 \pm 0.21$ \\
$\mathrm{C}$ & $0.6540 \pm 0.0047$ & $1.3815 \pm 0.0005$ & $0.5660 \pm 0.14$ \\
\hline
\end{tabular}

$3.3 \mathrm{pH}$

Based on Table 4, we can see that the $\mathrm{pH}$ of the supernatant from different particles increases as its size ranges increase. There is a slightly significant difference which ranges from 6.16 to 6.46 is acidic. The acidity of the banana peel powder for all varieties of size particles should be the same. The acidity of green banana peel (stage 2) powder also can be supported by similar findings in Cavendish banana varieties with $8 \%$ powder suspension in water (Salih et al., 2017). Paliyath and Murr (2007) confirmed earlier by stating that the young fruit tends to be more acidic and it is reduced as the ripening process occurs. The $\mathrm{pH}$ standard of wheat flour is in the range of 6 to 6.8 which puts it as an acidic food (Pearson, 2003). Since the banana peel powder's pH is in the same range as standard flour, it has good potential as a wheat substitute for food products without altering the $\mathrm{pH}$ of the whole ingredient.

Table 4. The $\mathrm{pH}$ of Saba banana peel powder for sample A $(\leq 125 \mu \mathrm{m}), \mathrm{B}(126-250 \mu \mathrm{m})$ and $\mathrm{C}(\geq 251 \mu \mathrm{m})$

\begin{tabular}{cc}
\hline Sample & $\mathrm{pH}$ \\
\hline A & $6.16 \pm 0.01$ \\
$\mathrm{~B}$ & $6.38 \pm 0.02$ \\
$\mathrm{C}$ & $6.46 \pm 0.01$ \\
\hline
\end{tabular}

\subsection{Water holding capacity}

Figure 1 represents an increase in water holding capacity as the temperature increases from $40^{\circ} \mathrm{C}, 60^{\circ} \mathrm{C}$ and $80^{\circ} \mathrm{C}$ for all sizes of powder. The water holding capacity is affected by several external factors and an increase in temperature could relate to its availability of water that can evaporate therefore the amount of water evaporates depends on the temperature where evaporation increases as temperature increases. The water holding capacity poses the highest value at $80^{\circ} \mathrm{C}$ (5.20 g to $6.45 \mathrm{~g} / \mathrm{g}$ of dry matter) on the other hand temperature of $40^{\circ} \mathrm{C}$ records the lowest value at the range of 3.83 to $5.88 \mathrm{~g} / \mathrm{g}$ dry matter. Besides, an increased size range of powder also increased water holding capacity with the highest value held by particles size ranging bigger than $250 \mu \mathrm{m}$. The water holding capacity could be related to the component of the particles since the porosity of banana peel powder is lower as the size of the particle gets higher. The results are in agreement with a study made by Savlak et al. (2016) on the increment of water holding capacity of banana powder due to the increment of particle size. High water holding capacity is also associated with the high pectin and hemicellulose concentration in fruits fibre. This claim can be supported by the $16.54 \%$ of pectin yield from unripe Saba banana peel (Castillo-Israel et al., 2015).

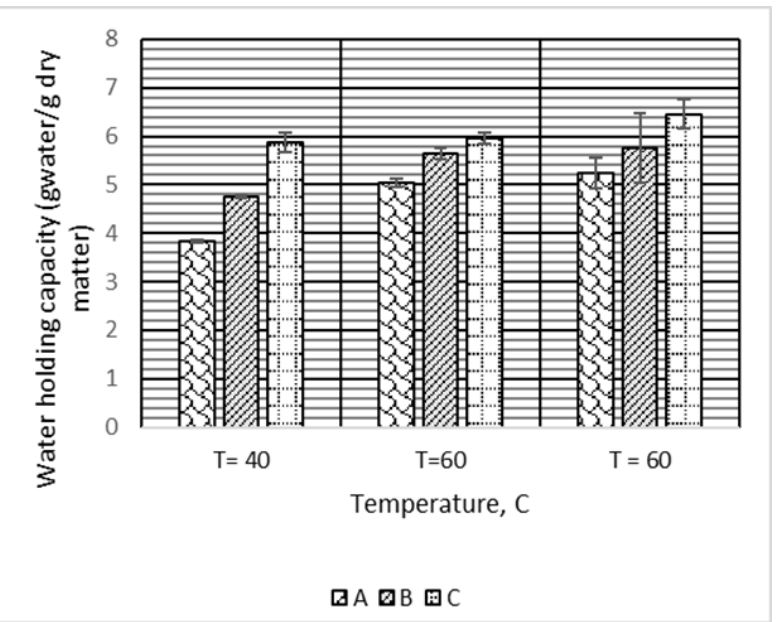

Figure 1. The water holding capacity of Saba banana peel powder for sample A $(\leq 125 \mu \mathrm{m}), \mathrm{B}(126-250 \mu \mathrm{m})$ and $\mathrm{C}(\geq 251$ $\mu \mathrm{m})$

Based on Figure 1, sample A with the lowest range of particle size has a higher mean water holding capacity starting from 3.83 to $5.20 \mathrm{~g}$ of water for every g of sample. The high water holding capacity is also attributed to swelling in which the volume or size of banana peel powder expands. This characteristic of banana peel powder has great potential in the noodle industry as approved by Ramli et al. (2001) in the utilization of banana peel powder in the yellow noodle. However, high swelling due to water holding or water retention capacity is not important as in the production of alkali noodles (Miskelly and Moss, 1985). This is because as the powder of banana peel expands, the dough produced is more brittle and needs optimization of noodle ingredients formulation as well as use a smaller size range than $125 \mu \mathrm{m}$. So, it is more suited to the production of other styles of Asian noodles (Widjaya 2010). Castelo-branco et al. (2017) in their study on the substitution of wheat flour to banana peel powder also 
proved its potential in the noodle industry.

\subsection{Oil holding capacity}

The oil holding capacity of banana peel powder of 3 samples in Figure 2 shows an increment of oil holding capacity that reflects on the increment of the size range of particles of banana peel powder. Apparently, the range of mean value of oil holding capacity for size particles for sample $\mathrm{C}$ is the highest ( 0.91 to $0.99 \mathrm{~g} / \mathrm{sample})$. The absorption of oil depended on the porosity of the food (Brannan et al., 2014). Besides, as the temperature increases, the oil holding capacity also increases. Brannan et al., (2014) stated that as the temperature increases, the water will steam out and leave the pore. Hence, it forms enough microstructures space to create very low positive vapour pressure and allows oil to enter the food. It is found that the mean oil holding capacity of stage 2 banana peel powder is much lower compared to wheat (1.46), rice flour (1.24), green gram flour (1.6) and potato flour (1.68) (Chandra and Samsher, 2013). By having low absorption of oil, it reduces the oil content in fried food such as deep-fried coated food products. The high water holding capacity characteristics are suitable for the food product that needs to restore moisture such as bread, cakey biscuit texture, processed meat, fillet or mutton. The low oil holding capacity characteristic is also beneficial to reduce the absorption of oil during frying.

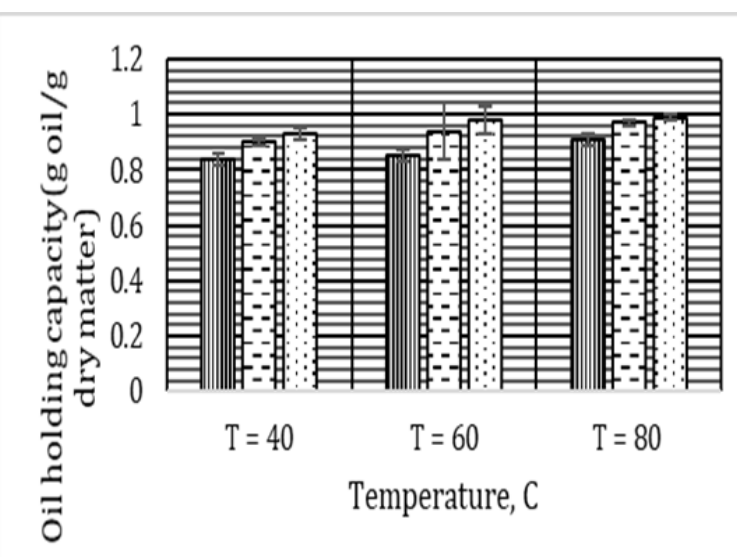

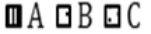

Figure 2. The oil holding capacity of Saba banana peel powder for sample A $(\leq 125 \mu \mathrm{m}), \mathrm{B}(126-250 \mu \mathrm{m})$ and $\mathrm{C}(\geq 251 \mu \mathrm{m})$

\subsection{Flow-ability (Hausner Ratio (HR) and Carr Index $(C I)$}

Apparently in Table 5 and Figure 3 the CI of banana peel powder reduced as the particle size of the powder decreased. Only banana peel powder at $>250 \mu \mathrm{m}$ has excellent flow compared to $125 \mu \mathrm{m}$ and $250 \mu \mathrm{m}$ which are in poor flow (Hausner, 1967). Meanwhile, when characterized with the Carr Index, only a size particle of
$>250 \mu \mathrm{m}$ is considered as a low cohesive group whereas the other size particles are in a high cohesive group.

Table 5. Carr index, Hausner ratio and flow properties of banana peel powder

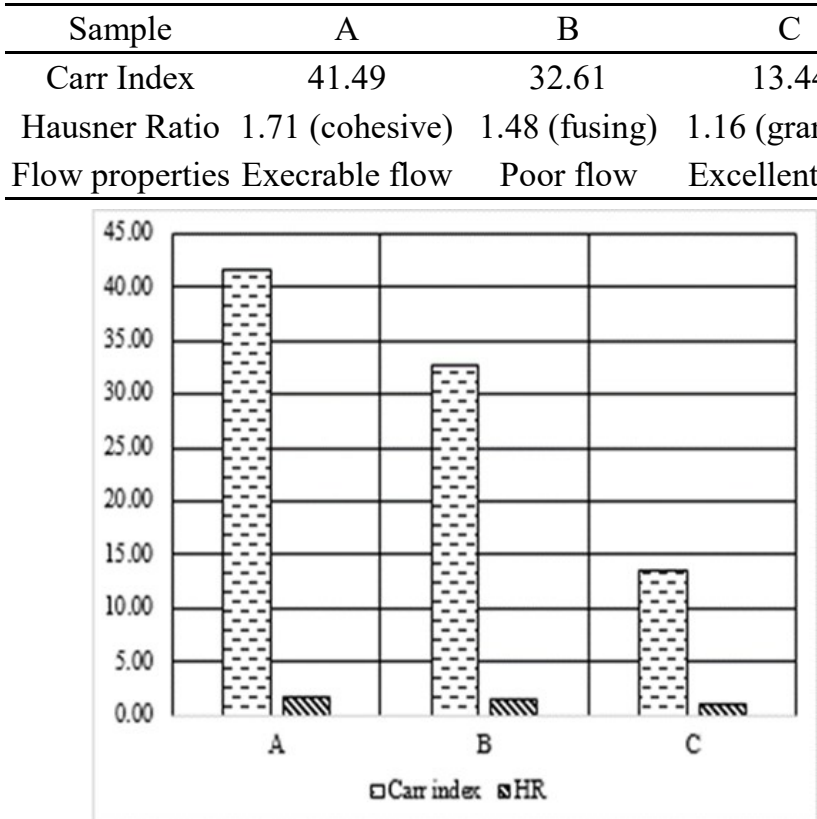

Figure 3. The Carr Index (CI) and Hausner Ratio of the Saba Banana Peel Powder at size particle of sample A, B, and C

\section{Conclusion}

In this project, the objectives are achieved. The properties of green banana peel (stage 2) powder at different particle sizes are studied based on the $\mathrm{pH}$, bulk density, true density and tapped density. From the result, the $\mathrm{pH}$ of banana peels range between 6.16-6.46 and it is classified as acidic. There are no significant differences in the bulk density, true density and tapped density of the banana peels powder where the highest bulk density recorded by sample $\mathrm{C}$ which is $0.5660 \mathrm{~g} / \mathrm{mL}$ followed by sample B and A which is $0.4714 \mathrm{~g} / \mathrm{mL}$ and $0.3878 \mathrm{~g} / \mathrm{mL}$ respectively. Besides, from density value, it shows that powder with sizes $>250 \mu \mathrm{m}$ has good flowability. The particle sizes of powder also affect the density of the powder which then will affect the flowability of powder in a fluidized mechanism for transport in the processing industry. The flowability of the materials is based on the scale of flowability of the Carr Index and the Hausner ratio. Here it is identified that sample $\mathrm{C}(>250 \mu \mathrm{m})$ has low cohesiveness compared to other sizes of A $(\leq 125$ $\mu \mathrm{m})$ and B (126-250 $\mu \mathrm{m})$. Through this study, sample C is more suitable for the production of bakery and cold meat products as it has the highest water holding capacity compared with sample A and B. Besides, the particle size of 125 and $250 \mu \mathrm{m}$ are more suitable for the food that needed removal of moisture like baking and frying. However, the utilization of banana peel powder on some food like noodles will need extra care on the formulation as it has a small diameter. High water 
holding capacity will cause the banana peel powder volume to lower the tensile strength of the noodle.

\section{Conflict of interest}

The authors declare no conflict of interest.

\section{Acknowledgements}

We acknowledge the financial support from the UPM grant with project grant number GPIPB/2018/9660301 which enabled us to carry out this study.

\section{References}

Anhwange, B.A., Ugye, T.J. and Nyiaatagher, T.D. (2009). Chemical Composition of Musa Sapientum Banana Peels. Electronic Journal of Environmental, Agricultural and Food Chemistry, 8(6), 437-442.

AOAC. (2006). Official Methods of Analysis Minerals Analysis Flame Atomic Absorption Spectroscopy (FAAS). 17th ed. Gaithersburg, USA: AOAC.

A, O.O., I, I.A., Pauline, I.A. and Ukamaka, O.G. (2016). Proximate Compositions of Fruits of Three Musa Species at Three Stages of Development. IOSR Journal of Dental and Medical Sciences, 15(6), 107117.

Berk, Z. (Ed.) (2013). Physical Properties of Food Materials. Food Process Engineering and Technology, p. 1-27. USA: Academic Press. https:// doi.org/10.1016/B978-0-12-415923-5.00001-0

Brannan, R.G., Mah, E., Schott, M., Yuan, S., Casher, K.L., Myers, A. and Herrick, C. (2014). Influence of Ingredients That Reduce Oil Absorption during Immersion Frying of Battered and Breaded Foods. European Journal of Lipid Science and Technology, 116(3), 240-254. https://doi.org/10.1002/ ejlt.201200308

Carr, R.L. (1965). Evaluating flow properties of solids. Chemical Engineering Journal, 72, 163-168.

Castelo-Branco, V.N., Guimarães, J.N., Souza, L., Guedes, M.R., Silva, P.M., Ferrão, L.L., Miyahira, R.F., Guimaraes, R.R., Freitas, S.M.L., Reis, M.C.D. and Zago, L. (2017). The use of green banana (Musa balbisiana) pulp and peel flour as an ingredient for tagliatelle pasta. Brazilian Journal of Food Technology, 20, e2016119. https:// doi.org/10.1590/1981-6723.11916

Castillo-Israel, K.A.T., Baguio, S.F., Diasanta, M.D.B., Lizardo, R.C.M., Dizon, E.I. and Mejico, M.I.F. (2015). Extraction and Characterization of Pectin from Saba Banana [Musa 'Saba' (Musa Acuminata $\mathrm{x}$ Musa Balbisiana)] Peel Wastes: A Preliminary
Study. International Food Research Journal, 22(1), 202-207.

Chandra, S. and Samsher. (2013). Assessment of functional properties of different flours. African Journal of Agricultural Research, 8, 4849-4852

FAMA. (2007). Agricultural Commodities Market Outlook. Malaysia: FAMA.

Gowe, C. (2015). Review on potential use of fruit and vegetables by-products as a valuable source of natural food additives. Food Science and Quality Management, 45, 47-61.

Gupta, K. and Joshi, V.K. (2000). Fermentative utilization of waste from food processing industry. In Verma, L.R. and Joshi, V.K. (Eds.) Postharvest Technology of Fruits and Vegetables: Handling Processing Fermentation and Waste Management. New Delhi, India: Indus Pub Co.

Miskelly, D.M. and Moss, H.J. (1985). Flour quality requirements for Chinese noodle manufacture. Journal of Cereal Science, 3(4), 379-387. https:// doi.org/10.1016/S0733-5210(85)80010-2

Othman, K.I., Karim, M.S.A., Karim, R., Adzhan, N.M. and Halim, N.A. (2013). Consumption Pattern on Fruits and Vegetables among Adults: A Case of Malaysia. Academic Journal of Interdisciplinary Studies, 2(8), 424-430. https://doi.org/10.5901/ ajis.2013.v2n8p424

Paliyath, G. and Murr, D.P. (2007). Biochemistry of Fruits. In Hui, Y.H. (Ed.) Food Biochemistry and Food Processing. USA: Blackwell Publishing.

Pearson, D. (2003). The chemical analysis of foods. $7^{\text {th }}$ ed. Harlow, UK: Longman Group Ltd.

Philippine Statistics Authority. (2017). 2015-2019 Crops statistics of the Philippines. Philippines: Philippine Statistics Authority.

Ramli, S., Alkarkhi, A.F.M., Yeoh, S.Y. and Easa, A.M. (2001). Utilization of Green and Ripe Banana Peel as a Functional Ingredient in Yellow Noodle. Asian Journal of Food and Agro-Industry, 2(3), 302-310.

Salih, Z.A., Siddeeg, A., Taha, R.T., Bushra, M., Ammar, A.F. and Ali, A.O. (2017). Physicochemical and Functional Properties of Pulp and Peel Flour of Dried Green and Ripe Banana Cavendish. International Journal of Research in Agricultural Sciences, 4(6), 348-353.

Savlak, N., Türker, B. and Nazlıcan, Y. (2016). Effects of Particle Size Distribution on Some Physical, Chemical and Functional Properties of Unripe Banana Flour. Food Chemistry, 213, 180-186. https://doi.org/10.1016/j.foodchem.2016.06.064

Shian, T.E. and Abdullah, A. (2012). Antioxidant properties of three banana cultivars (Musa 
acuminata 'Berangan','Mas' and 'Raja') extracts. Sains Malaysiana, 41(3), 319-324.

Tchobanoglous, G., Theisen, H. and Vigil, S. (1993). Integrated solid waste management: Engineering principles and management issues. USA: McGrawHill.

Tomar, M., Kumar, S.A. and Raj, S.A. (2017). Effect of moisture content of excipient (microcrystalline cellulose) on direct compressible solid dosage forms. International Journal of Pharmaceutical Sciences and Research, 8(1), 282-288.

Turchiuli, C., Eloualia, Z., El Mansouri, N. and Dumoulin, E. (2005). Fluidised bed agglomeration: Agglomerates shape and end-use properties. Powder Technology, 157(1-3), 168-175. https:// doi.org/10.1016/j.powtec.2005.05.024

Valmayor, R.V., Jamaluddin, S.H., Silayoi, B., Kusumo, S., Danh, L.D., Pascua, O.C. and Espino, R.R.C. (2000). Banana cultivar names and synonyms in Southeast Asia. France: International Network for the Improvement of Banana and Plantain.

Wachirasiri, P., Julakarangka, S. and Wanlapa, S. (2009). The effects of banana peel preparations on the properties of banana peel dietary fibre concentrate. Songklanakarin Journal of Science and Technology, 31(6), 605-611.

Widjaya, C. (2010). The Impact of Ingredient Formulation and Processing Parameters on Colour and Texture of Instant Noodles. Melbourne, Australia: RMIT University. PhD Dissertation. 